\title{
Determinants of the Sensitivity of Human Small-cell Lung Cancer Cell Lines to Methotrexate
}

\author{
Gregory A. Curt, Jacques Jolivet, Desmond N. Carney, Brenda D. Bailey, \\ James C. Drake, Neil J. Clendeninn, and Bruce A. Chabner \\ Clinical Pharmacology and NCI-Navy Oncology Branches, Division of Cancer Treatment, \\ National Cancer Institute, Bethesda, Maryland 20205
}

\begin{abstract}
We have characterized the determinants of methotrexate (MTX) responsiveness in eight patient-derived cell lines of small-cell lung cancer (SCLC). Clonogenic survival was correlated with factors known to affect sensitivity to drug. NCI-H209 and NCIH128 were most drug sensitive, with drug concentrations required to inhibit clonogenic survival by $50 \%$ with $<0.1 \mu \mathrm{M}$ MTX. Six cell lines (NCI-H187, NCI-H345, NCI-H60, NCI-H524, NCIH146, and NCI-N417D) were relatively drug resistant. In all cell lines studied, higher molecular weight MTX-polyglutamates (MTX-PGs) with 3-5 glutamyl moieties (MTX-Glu 3 through MTX-Glu ) were selectively retained. Relative resistance to low $(1.0 \mu \mathrm{M})$ drug concentrations appeared to be largely due to decreased intracellular metabolism of MTX. Five of the six resistant lines were able to synthesize polyglutamates at higher (10 $\mu \mathrm{M})$ drug concentrations, although one resistant cell line (NCIN417D) did not synthesize higher molecular weight MTX-PGs, even after exposure to $10 \mu \mathrm{M}$ drug. Two cell lines with resistance to $10 \mu \mathrm{M}$ MTX (NCI-H146 and NCI-H524) synthesized and retained higher molecular weight MTX-PGs in excess of binding capacity after exposure to $10 \mu M$ drug. However, the specific activity of thymidylate synthase in these cell lines was low. MTX sensitivity in patient-derived cell lines of SCLC requires the ability of cells to accumulate and retain intracellular drug in the form of polyglutamate metabolites in excess of dihydrofolate reductase, as well as a high basal level of consumption of reduced folates in the synthesis of thymidylate.
\end{abstract}

\section{Introduction}

Methotrexate (MTX) ${ }^{1}$ is the most widely used antimetabolite in cancer chemotherapy, demonstrating consistent antitumor activity in osteosarcoma, choriocarcinoma, lymphoma, acute leukemia, breast cancer, cancer of the head and neck, and smallcell carcinoma of the lung (SCLC) (1). Its primary mechanism of action - the inhibition of dihydrofolate reductase (DHFR) -

Received for publication 19 March 1984 and in revised form 10 June 1985.

1. Abbreviations used in this paper: DHFR, dihydrofolate reductase; dUMP, diocyuridylate; FCS, fetal calf serum; $\mathrm{FH}_{2}$, dihydrofolate; $\mathrm{IC}_{50}$, drug concentration required to inhibit clonogenic survival by $50 \%$; MTX, methotrexate (4-amino-10-methyl-pteroylglutamic acid); MTX-PGs, MTX polyglutamates; MTX-Glutamyl ${ }_{1-5}$, MTX-Glu ${ }_{1}$, MTX-Glu MTX-Glu ${ }_{3}$, MTX-Glu , and MTX-Glu, , respectively; SCLC, small-cell lung cancer; TS, thymidylate synthase.

J. Clin. Invest.

(c) The American Society for Clinical Investigation, Inc.

0021-9738/85/09/1323/07 $\$ 1.00$

Volume 76, October 1985, 1323-1329 is well established, and a variety of possible mechanisms of resistance have been demonstrated in tissue culture experiments and in patient studies.

After entering cells by energy-dependent, carrier-mediated transport (2), MTX binds stoichiometrically to its target enzyme, DHFR, and prevents repletion of biologically active reduced folate pools necessary for de novo purine and thymidylate synthesis. Since intracellular folates are oxidized only during thymidylate synthesis, the activity of this pathway is a critical determinant of MTX responsiveness (3-6). In addition, free drug in excess of intracellular binding capacity is necessary for cytotoxicity. In the absence of free drug, intracellular physiologic folates can compete for binding sites on DHFR, reversing enzyme inhibition (7-9). The transformation of MTX to polyglutamyl derivatives results in the formation of active metabolites of the drug that, when present in excess of the intracellular binding capacity, results in prolonged inhibition of DHFR (10-17). In addition, MTX polyglutamates (MTX-PGs) may have additional sites of action as inhibitors of aminoimidazole carboxamide ribonucleotide transformylase (de novo purine synthesis) (18) and thymidylate synthase (TS) (19).

In vitro selection of MTX-resistant tumor cells has provided detailed insights into diverse mechanisms of drug resistance. Mutants with defective drug transport (20-22) and decreased DHFR affinity for MTX (23-25) have been described. Cellular resistance may also be conferred by amplification of the gene coding for DHFR, resulting in high intracellular target enzyme levels (26-30). Low levels of TS, resulting in decreased intracellular folate oxidation (3-6), are also associated with resistance. More recently it has been demonstrated that cells selected for in vitro MTX resistance may be defective in metabolism of drug to polyglutamate species (31).

Despite considerable understanding of in vitro mechanisms of MTX resistance, relatively little is known about the determinants of clinical drug response. Bertino and co-workers (32) were the first to demonstrate that acute rises in intracellular MTX binding capacity could be a determinant of drug resistance in patients with acute leukemia. More recently it has been shown that in vivo resistance after MTX treatment may be due to DHFR gene amplification and elevated target enzyme levels (3337). Still, a complete understanding of factors mediating clinical drug resistance has not been achieved.

In the present studies, we have analyzed potential determinants of MTX responsiveness in eight cell lines of SCLC derived from patients who were either newly diagnosed or in relapse after combination chemotherapy including MTX (38). Cell lines were characterized with respect to growth rate, clonogenic survival after MTX exposure, adequacy of transport to produce saturation of intracellular binding sites, DHFR specific activity, affinity of target enzyme for drug, TS specific activity, and synthesis and retention of MTX-PGs. 


\section{Methods}

Chemicals. $\left[3^{\prime}, 5^{\prime}, 9-{ }^{3} \mathrm{H}\right] \mathrm{MTX}(20 \mathrm{Ci} / \mathrm{mmol} \mathrm{sp}$ act $)$ was purchased from Amersham Corp. (Arlington Heights, IL) and further purified by DEAEcellulose chromatography with elution along a linear gradient of $0.1-0.4$ $\mathrm{M} \mathrm{NH}_{4} \mathrm{HCO}_{3}$ (2). Unlabeled MTX was obtained from the Drug Synthesis and Chemistry Branch, National Cancer Institute (Bethesda, MD) and purified by the same procedure. $\left[5-{ }^{3} \mathrm{H}\right]$ deoxyuridylate (dUMP) $(14.8 \mathrm{Ci} /$ mmol sp act) was obtained from Amersham Corp. L-glutamine was obtained from Flow Laboratories (McLean, VA), DEAE-Sephacel from Pharmacia Fine Chemicals (Uppsala, Sweden), and Ready-Solv scintillation cocktail from Beckman Laboratories (Fullerton, CA). Dihydrofolate $\left(\mathrm{FH}_{2}\right)$ and NADPH were purchased from Sigma Chemical Co. (St. Louis, MO). All other chemicals were of reagent grade and were purchased from Fisher Scientific Co. (Pittsburgh, PA). Fetal calf serum (FCS) was obtained from Biofluids Inc. (Rockville, MD) and RPMI1620 from Gibco Laboratories (Grand Island, NY). Penicillin and streptomycin were obtained from the National Institutes of Health Media Unit (Bethesda, MD) and agarose from Difco Laboratories (Detroit, MI).

Propagation of cells in culture. The establishment and characterization of continuous clonable cell lines of SCLC have been previously described $(39,40)$. These cells were propagated in suspension culture in $75-\mathrm{cm}^{2}$ plastic flasks (Costar, Cambridge, MA) using RPMI-1620 media supplemented with $10 \%$ heat-inactivated FCS, penicillin $(124 \mu \mathrm{g} / \mathrm{ml})$, streptomycin $(270 \mu \mathrm{g} / \mathrm{ml})$, and L-glutamine $(2 \mathrm{mM})$ under $5 \% \mathrm{CO}_{2}$ at $37^{\circ} \mathrm{C}$. Doubling times of cell lines in log-phase growth were determined by inoculating individual $25-\mathrm{cm}^{2}$ plastic flasks (Costar) with $10^{5} \mathrm{cells} / \mathrm{ml}$. At specific times over a 7-d interval, cells were treated with $0.05 \%$ trypsin and $0.06 \%$ EDTA for $10 \mathrm{~min}$ at $37^{\circ} \mathrm{C}$ and counted in a model B Coulter counter (Coulter Electronics, Hialeah, FL).

Cytotoxicity studies. The effects of drug exposure were determined using a soft-agar clonogenic assay (41). Cells $\left(5 \times 10^{5}\right.$ cells $\left./ \mathrm{ml}\right)$ were exposed to drug in complete medium for $24 \mathrm{~h}$, washed three times in iced phosphate-buffered saline, and then plated in $0.37 \%$ agarose in complete medium above an agarose feeder layer (42). Cultures were incubated at $37^{\circ} \mathrm{C}$ under $5 \% \mathrm{CO}_{2}$ and colonies counted at $10-20 \mathrm{~d}$ with invertedphase microscopy.

DHFR specific activity and affinity for MTX. DHFR activity was determined spectrophotometrically (43) in cytosol preparations of cells in log-phase growth. Activity was expressed as nanomoles NADPH converted per minute per milligram protein. Protein was determined by the Lowry technique (44). The dissociation constant $\left(K_{d}\right)$ of MTX from target enzyme was also determined on cytosol preparations using a competitive protein-binding assay (45) and Scatchard analysis (46).

TS activity. The activity of TS in cytosol preparations of cells in logphase growth was determined using the tritium release procedure of Roberts (47). Assays were performed in a total volume of $200 \mu \mathrm{l} \mathrm{con-}$ taining $\left[{ }^{5-10} \mathrm{~N}\right]$ methylene tetrahydrofolate, $1 \times 10^{-5} \mathrm{M}$ dUMP (Sigma Chemical Co.), and $3.04 \mathrm{pmol}$ of $\left[5-{ }^{3} \mathrm{H}\right] \mathrm{dUMP}$ (Moravek, Brea, CA) in $100 \mathrm{mM} 2$-mercaptoethanol. The reaction was initiated by adding $20 \mu \mathrm{l}$ of cell extract. After $30 \mathrm{~min}$ of incubation at $37^{\circ} \mathrm{C}$ the reaction was stopped with $100 \mu \mathrm{l}$ of $20 \%$ trichloracetic acid. Unreacted $\left[5-{ }^{3} \mathrm{H}\right] \mathrm{dUMP}$ was removed with an albumin-coated charcoal slurry, allowed to stand for $10 \mathrm{~min}$ at room temperature, then spun down at $1,000 \mathrm{~g}$ for $30 \mathrm{~min}$. A $250-\mu 1$ sample was assayed for tritium activity and specific activity expressed as picomoles dUMP converted per minute per milligram protein. All assays were performed at least in triplicate with standard deviations $<10 \%$ about the mean.

Determination of MTX-PG synthesis and bound and free MTX levels. Logarithmically growing cells $\left(5 \times 10^{5} / \mathrm{ml}\right.$, total volume $\left.=20 \mathrm{ml}\right)$ were incubated in complete medium containing 1.0 or $10.0 \mu \mathrm{M}\left[{ }^{3} \mathrm{H}\right] \mathrm{MTX}$. After 1- and 24-h incubation, $2.5 \times 10^{6}$ cells were harvested to determine total intracellular drug and metabolite levels. Bound and free drug levels were determined as described previously (14). At the end of 24-h drug incubation, the remaining cells were washed in iced PBS three times, resuspended in an equal volume of drug-free complete media, and incubated at $37^{\circ} \mathrm{C}$ for an additional $24 \mathrm{~h}$ in order to determine drug efflux patterns. At each time point, cells were processed for intracellular polyglutamate formation as previously described (14).

\section{Results}

Drug sensitivity studies. The clonogenic survival of the eight cell lines after a 24-h incubation with $0.1,1.0$, or $10.0 \mu \mathrm{M}$ MTX fell into two distinct patterns (Fig. 1). Both NCI-H209 and NCI$\mathrm{H} 128$ were highly drug sensitive, with cloning inhibited by $>80 \%$ at $0.1 \mu \mathrm{M}$ drug. Cell lines NCI-H187, NCI-H345, NCI-H60, NCI-H524, NCI-H146, and NCI-N417D were considerably more drug resistant, with drug concentrations required to inhibit clonogenic survival by $50 \%\left(\mathrm{IC}_{50} \mathrm{~S}\right)$ ranging from 0.35 to $5.2 \mu \mathrm{M}$ drug. There was no consistent relationship between sensitivity and a history of prior MTX treatment or growth rate. In addition, there was no direct relationship between DHFR specific activity and drug responsiveness. The affinity of DHFR for drug from individual cell lines varied from a $K_{\mathrm{d}}$ of $0.89-2.72 \times 10^{-11} \mathrm{M}$, but again there was no correlation of these values with resistance (Table I).

Drug uptake and retention. The intracellular drug profile of all lines was examined after $1 \mathrm{~h}$ of drug exposure, at the completion of $24 \mathrm{~h}$ incubation, and after $24 \mathrm{~h}$ efflux in drug-free media: Parameters studied at each time point included determination of free intracellular drug levels and drug bound to target enzyme, as well as metabolism to and subsequent retention of MTX-PGs.

As shown in Table II, all cell lines accumulated free drug in excess of cellular binding capacity after a 1-h exposure to $1 \mu \mathrm{M}$ MTX. During the 24-h period of MTX incubation, levels of free intracellular drug continued to increase in association with the formation of intracellular polyglutamates. During the 24-h incubation, an acute rise in drug binding capacity was also observed. This increase in intracellular binding sites was greatest in the most drug-resistant lines. In NCI-H146, this represented a sixfold elevation, while in NCI-N417D the 24-h intracellular binding capacity was eightfold higher than 1-h levels. Overall, there was a twofold increase in binding capacity in sensitive cell lines versus an average fourfold increase in resistant lines.

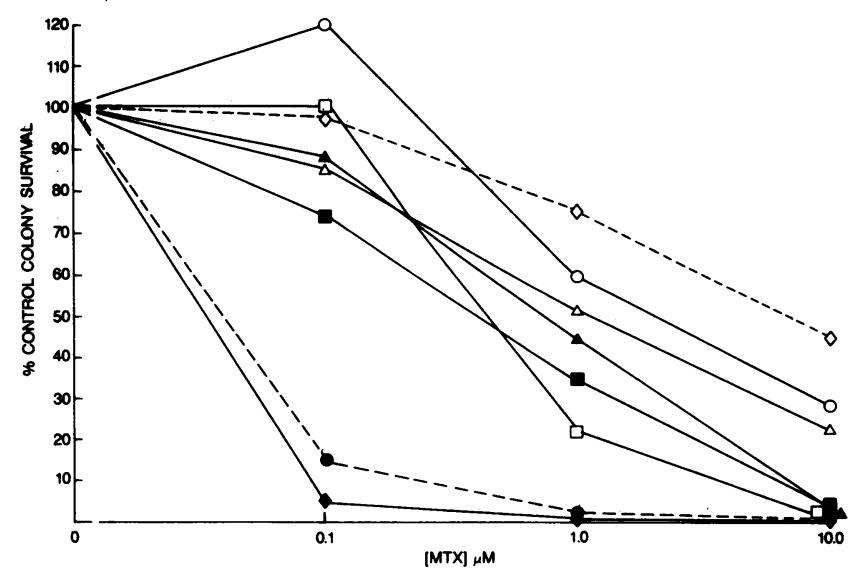

Figure 1. Clonogenic survival of human SCLC cell lines after 24-h

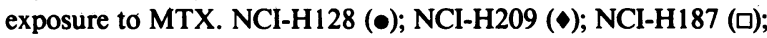
NCI-H345 (घ); NCI-H60 (ه); NCI-H524 ( $\Delta)$; NCI-H146 (0); and NCI-N417 ( $\diamond)$. 
Table I. Characteristics of Eight Patient-derived Cell Lines of Human SCLC

\begin{tabular}{|c|c|c|c|c|c|c|}
\hline Cell line & Prior therapy & Doubling time & $\begin{array}{l}\text { DHFR specific activity } \\
\text { (nmol NADPH } \\
\text { converted/mg/min) }\end{array}$ & $K_{\mathrm{d}}$ DHFR & $\mathrm{IC}_{50}$ & $\begin{array}{l}\text { TS specific activity } \\
\text { (pmole dUMP } \\
\text { converted } \mathrm{mg} / \mathrm{min} \text { ) }\end{array}$ \\
\hline & & $h$ & & $10^{-11} M$ & & \\
\hline NCI-H128 & - & 79 & 0.96 & 2.72 & 0.04 & 122.0 \\
\hline NCI-H209 & + & 96 & 1.70 & 1.03 & 0.03 & 68.6 \\
\hline NCI-H187 & - & 60 & 1.50 & 0.89 & 0.35 & 37.8 \\
\hline NCI-H345 & + & 112 & 3.75 & 2.72 & 0.42 & 34.8 \\
\hline NCI-H60 & + & 74 & 1.06 & 2.13 & 0.65 & 54.9 \\
\hline $\mathrm{NCI}-\mathrm{H} 524$ & + & 120 & 1.48 & 5.47 & 1.0 & 10.1 \\
\hline NCI-H146 & + & 70 & 1.92 & 1.33 & 1.60 & 9.3 \\
\hline NCI-N417D & - & 24 & 1.58 & 1.69 & 5.20 & 42.3 \\
\hline
\end{tabular}

Intracellular formation and retention of $M T X-P G$ s after 1 $\mu M M T X$ exposure: relation to maintenance of free intracellular drug. We next examined whether a relationship existed between drug sensitivity and drug accumulation or retention. As shown in Table II, although the absolute amount of free drug attained

Table II. Bound and Free Intracellular Drug in Human SCLC Cell Lines*

\begin{tabular}{|c|c|c|c|c|}
\hline \multirow[b]{2}{*}{ Cell line } & \multirow{2}{*}{$\begin{array}{l}\begin{array}{l}\text { MTX } \\
\text { bound }\end{array} \\
1.0 \mu \mathrm{M} \\
\text { MTX }\end{array}$} & \multirow{2}{*}{$\begin{array}{l}\begin{array}{l}\text { MTX } \\
\text { free }\end{array} \\
\begin{array}{l}1.0 \mu \mathrm{M} \\
\text { MTX }\end{array}\end{array}$} & \multirow{2}{*}{$\begin{array}{l}\begin{array}{l}\text { MTX } \\
\text { bound }\end{array} \\
10 \mu M \\
\text { MTX }\end{array}$} & \multirow{2}{*}{$\begin{array}{l}\begin{array}{l}\text { MTX } \\
\text { free }\end{array} \\
\begin{array}{l}10 \mu M \\
\text { MTX }\end{array}\end{array}$} \\
\hline & & & & \\
\hline & $\mathrm{nmol} / \mathrm{g}$ & $\mathrm{nmol} / \mathrm{g}$ & $n m o l / g$ & $\mathrm{nmol} / \mathrm{g}$ \\
\hline \multicolumn{5}{|l|}{ Sensitive } \\
\hline \multicolumn{5}{|l|}{ NCI-H209 } \\
\hline $1 \mathrm{~h}$ & 0.48 & 1.09 & - & - \\
\hline $24 \mathrm{~h}$ (\% increase) & $1.46(304)$ & 4.54 & - & - \\
\hline 24-h efflux & 1.82 & 1.25 & - & - \\
\hline \multicolumn{5}{|l|}{ NCI-H128 } \\
\hline $1 \mathrm{~h}$ & 0.94 & 1.46 & - & - \\
\hline $24 \mathrm{~h}$ (\% increase) & $1.58(168)$ & 4.05 & - & - \\
\hline 24-h efflux & 3.56 & 1.76 & - & - \\
\hline \multicolumn{5}{|l|}{ Resistant } \\
\hline \multicolumn{5}{|l|}{ NCI-H187 } \\
\hline $1 \mathrm{~h}$ & 1.84 & 3.28 & 2.80 & 18.60 \\
\hline $24 \mathrm{~h}$ (\% increase) & $3.60(195)$ & 5.30 & $4.98(177)$ & 36.50 \\
\hline 24-h efflux & 2.90 & 0.40 & 3.30 & 2.50 \\
\hline \multicolumn{5}{|l|}{ NCI-H345 } \\
\hline $1 \mathrm{~h}$ & 1.61 & 0.94 & 4.20 & 8.93 \\
\hline $24 \mathrm{~h}$ (\% increase) & $3.38(210)$ & 3.38 & $4.39(104)$ & 18.75 \\
\hline 24-h efflux & 1.46 & 0.20 & 1.93 & 0.91 \\
\hline \multicolumn{5}{|l|}{ NCI-H60 } \\
\hline $1 \mathrm{~h}$ & 0.60 & 2.53 & 2.89 & 21.21 \\
\hline $24 \mathrm{~h}$ (\% increase) & $1.74(290)$ & 4.23 & $2.44(-15)$ & 46.41 \\
\hline 24-h efflux & 1.41 & 0.17 & 2.04 & 7.68 \\
\hline \multicolumn{5}{|l|}{ NCI-H524 } \\
\hline $1 \mathrm{~h}$ & 0.88 & 0.88 & 3.00 & 6.40 \\
\hline $24 \mathrm{~h}$ (\% increase) & $2.94(334)$ & 4.41 & $7.38(246)$ & 16.40 \\
\hline $24 \mathrm{~h}$ efflux & 1.64 & 0.67 & 5.00 & 1.86 \\
\hline \multicolumn{5}{|l|}{ NCI-H146 } \\
\hline $1 \mathrm{~h}$ & 0.55 & 1.16 & 2.70 & 14.40 \\
\hline $24 \mathrm{~h}$ (\% increase) & $3.50(636)$ & 4.70 & $6.70(248)$ & 28.60 \\
\hline 24-h efflux & 3.50 & 0.28 & 5.00 & 1.80 \\
\hline \multicolumn{5}{|l|}{ NCI-N417D } \\
\hline $1 \mathrm{~h}$ & 0.43 & 1.82 & 3.29 & 14.98 \\
\hline $24 \mathrm{~h}$ (\% increase) & $3.67(853)$ & 3.40 & $3.08(-6)$ & 17.48 \\
\hline 24-h efflux & 2.12 & 0.13 & 2.01 & 0.13 \\
\hline
\end{tabular}

* After 1.0 and $10.0 \mu \mathrm{m}$ MTX exposure for $1 \mathrm{~h}, 24 \mathrm{~h}$, and subsequent $24-\mathrm{h}$ efflux in drug-free media. after $24 \mathrm{~h}$ of $1 \mu \mathrm{M}$ incubation was similar in all lines (range $3.38-5.30 \mathrm{nM} / \mathrm{g}$ ), there was great variation in the retention of drug after removal of extracellular MTX. No correlation was observed between the amount of free drug present at the end of incubation and at end of efflux. However, there was a direct correlation between drug sensitivity and drug retention after efflux. For example, NCI-H209 and NCI-H128 were sensitive to a 24-h incubation in $1.0 \mu \mathrm{M}$ MTX. In both of these cell lines, significant levels of free intracellular drug (1.25 and $1.76 \mathrm{nmol} /$ $\mathrm{g}$, respectively) remained after $24 \mathrm{~h}$ in drug-free media. This represented 27 and $43 \%$ of free drug present after the completion of drug exposure. The remaining five SCLC cell lines were more resistant to $1.0 \mu \mathrm{M}$ MTX. In these lines, only $0.13-0.67 \mathrm{nM}$ drug/g protein remained after efflux, representing $3.8-15.2 \%$ of free drug initially present after incubation.

The critical determinant of drug retention and prolonged target enzyme saturation was intracellular metabolism of MTX to MTX-PGs with three or more glutamyl groups. These data are shown in Fig. 2, where incubation times of 1 and $24 \mathrm{~h}$, and $24 \mathrm{~h}$ of efflux in drug-free media are shown. No cell line was capable of synthesizing higher molecular weight MTX-PGs during the first hour of drug incubation. However, after $24 \mathrm{~h}$ incubation, MTX-PGs with three or more glutamyl moieties became the predominant intracellular form of drug in both sensitive cell lines, $\mathrm{NCI}-\mathrm{H} 209$ and $\mathrm{NCI}-\mathrm{H} 128$, being present at more than twice the intracellular binding capacity. During the 24-h period in drug-free media, MTX and MTX-Glu ${ }_{2}$ readily effluxed cells, while the MTX-PGs with longer polyglutamate tails (3-5) were relatively conserved and remained present in excess of intracellular binding capacity at the end of efflux in these two sensitive cell lines, continuing to saturate intracellular binding sites in the absence of extracellular drug.

These results differed from the findings in the six SCLC cell lines resistant to $1-\mu \mathrm{M}$ drug exposure. In these cell lines, the concentration of higher polyglutamates was much less than the DHFR binding capacity. As shown in Fig. 2, only small amounts of MTX-Glu 3 -MTX-Glu 5 were formed after 24-h drug incubation of NCI-H187, NCI-H345, NCI-H60, NCI-H524, NCIH146, and NCI-N417D, and at no time were the levels of these higher molecular weight metabolites sufficient by themselves to saturate $>69 \%$ of the intracellular binding capacity. Notably, free drug levels after $24 \mathrm{~h}$ of incubation with $1 \mu \mathrm{M}$ MTX consisted predominantly of MTX and MTX-Glu to those found in the drug-sensitive NCI-H209 and NCI-H128 cell lines. However, after the $24-\mathrm{h}$ incubation in drug-free media, 


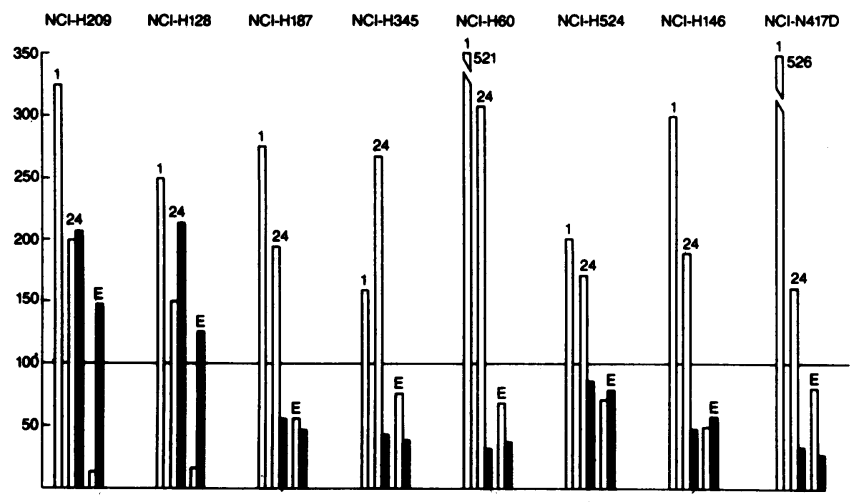

Figure 2. Total intracellular drug (MTX plus MTX-Glu 2 , $\square$; MTX$\mathrm{Glu}_{3}$ plus MTX-Glu 4 plus MTX-Glu,, ), expressed as percentage saturation of intracellular binding capacity, after incubation with $1.0 \mu \mathrm{M}$ MTX for $1 \mathrm{~h}, 24 \mathrm{~h}$, and subsequent 24-h efflux in drug-free media.

MTX and MTX-Glu 2 effluxed readily, and although the small quantities of longer polyglutamates were retained during efflux, their initial synthesis was insufficient to maintain drug in excess of the binding capacity.

Closer study of individual polyglutamate metabolites confirmed that, as determined in prior experiments with breast cancer cell lines (13) and small-cell cell lines (17), drug retention correlates with glutamyl chain length. Thus, for all cell lines after a 24-h exposure to $1.0 \mu \mathrm{M}$ MTX, only $4-24 \%$ of parent drug present at the end of drug incubation remained after 24-h efflux, while $25 \%$ of MTX-Glu, $70 \%$ of MTX-Glu, $75 \%$ of MTX-Glu , and $83 \%$ of MTX-Glu 5 were retained. Of the cell lines with relative resistance to $1 \mu \mathrm{M}$ MTX, only NCI-H187 synthesized small amounts of MTX-Glu $(<1 \%$ of total intracellular drug). No other resistant line synthesized polyglutamates larger than MTX-Glu , and this metabolite was consistently $<4 \%$ of total intracellular drug after $1 \mu \mathrm{M}$ incubation for $24 \mathrm{~h}$. However, after the same drug exposure in the MTX-sensitive cell

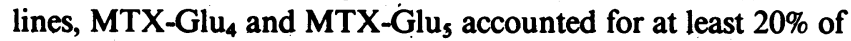
total intracellular drug.

Intracellular formation and retention of MTX-PGs after 10 $\mu M M T X$ exposure: determinants of sensitivity. The determinants of tumor cell sensitivity, including drug accumulation, metabolism, and retention, were examined at $10 \mu \mathrm{M}$ MTX in the six resistant cell lines that had low levels of MTX polyglutamation after $1-\mu \mathrm{M}$ drug incubation. As shown in Fig. 3 and Table II, at the higher drug concentration, total intracellular drug levels after both 1- and 24-h incubation were 3.4- to 10-fold higher than the corresponding level achieved at $1.0 \mu \mathrm{M}$ MTX. The intracellular binding capacity as measured by DEAE-Sephacel chromatography at $1 \mathrm{~h}$ was somewhat higher (1.5-4.9 times) in cells exposed to $10 \mu \mathrm{M}$ drug as compared with the binding capacity at $1 \mu \mathrm{M}$. These differences became less marked with continued drug exposure, and measured binding capacities were similar at $24 \mathrm{~h}$ incubation and efflux for cells exposed to either 1 or 10 $\mu \mathrm{M}$ drug. The most remarkable changes in intracellular drug levels in cells exposed to $10 \mu \mathrm{M}$ MTX was a general increase in free drug levels at all measured time points, including after 24 $h$ of efflux in drug-free media (Table II). Thus, while free drug after efflux had been between 0.13 and $0.67 \mathrm{nM} / \mathrm{g}$ after $1.0-\mu \mathrm{M}$ exposure, free drug levels after $10.0 \mu \mathrm{M}$ incubation and 24-h efflux increased more than fourfold in all cell lines tested except $\mathrm{NCI}-\mathrm{N} 417 \mathrm{D}$, which remained at $0.13 \mathrm{nM} / \mathrm{g}$. Again, the critical

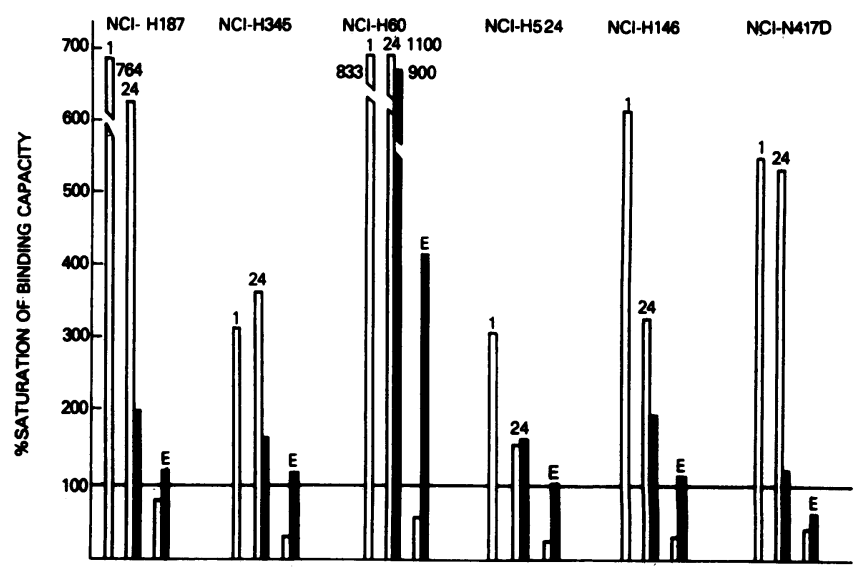

Figure 3. Total intracellular drug (MTX plus MTX-Glu,$~ \square$; MTX$\mathrm{Glu}_{3}$ plus MTX-Glu plus MTX-Glu, $_{5}$, ), expressed as percentage maturation of intracellular binding capacity after incubation with 10.0 $\mu \mathrm{M}$ MTX for $1 \mathrm{~h}, 24 \mathrm{~h}$, and subsequent 24-h efflux in drug-free media.

determinant for drug retention above intracellular binding capacity and drug sensitivity was the extent of metabolism to MTX-Glu 3-5.

As shown in Fig. 3, the absolute amounts of higher molecular weight MTX-PGs increased substantially after $10 \mu \mathrm{M}$ drug exposure. NCI-H345, NCI-H60, and NCI-H146, which had previously synthesized no MTX-Glu this metabolite equal to or greater than those found in the sensitive cell lines after $1.0 \mu \mathrm{M}$ drug exposure. Further, intracellular levels of MTX-Glu 3 and MTX-Glu 4 were increased after $10 \mu \mathrm{M}$ MTX exposure in all cell lines as compared with their levels after $1 \mu \mathrm{M}$ drug.

As had been observed after exposure to $1.0 \mu \mathrm{M}$ drug, MTX and MTX-Glu ${ }_{2}$ rapidly effluxed from the cells in drug-free media, while higher molecular weight metabolites were again selectively retained (Fig. 3). Sufficient quantities of these derivatives were present after the 24-h incubation to more than saturate DHFR after $24 \mathrm{~h}$ in drug-free media in all cell lines except NCI-N417D (Fig. 3) These increases were associated with $>90 \%$ inhibition of colony formation in three of the six cell lines (Fig. 1) when MTX-PG levels were sustained during the period of drug efflux.

NCI-H146, NCI-H524, and NCI-N417D remained relatively drug resistant (Fig. 1) at $10 \mu \mathrm{M}$ MTX. In these cell lines, clonogenic survival was $>20 \%$ control after exposure to $10 \mu \mathrm{M}$ MTX for $24 \mathrm{~h}$. These three cell lines were characterized by specific biochemical alterations that further modulated response.

In both $\mathrm{NCI}-\mathrm{H} 146$ and $\mathrm{NCI}-\mathrm{H} 524$, exposure to $10.0 \mu \mathrm{M}$ MTX for $24 \mathrm{~h}$ was adequate for the synthesis of sufficient MTXPGs for prolonged enzyme saturation. However, the specific activity of TS was found to be considerably lower in these lines, 9.3 and 10.1 U, respectively (Table I), than in the five cell lines sensitive to $10 \mu \mathrm{M}$ MTX. The third resistant cell line, NCIN417D, metabolized MTX inefficiently and was the only cell line incapable of forming the most avidly retained PG, MTXGlu $_{5}$, after $10 \mu \mathrm{M}$ drug exposure. Thus, even after exposure to high drug concentrations, insufficient MTX-PGs were formed for prolonged enzyme saturation.

These clinically derived SCLC cell lines varied by $>100$-fold in their sensitivity to MTX. Responsiveness to 1.0 and $10.0 \mu \mathrm{M}$ drug correlated best with the ability to synthesize higher molec- 
ular weight MTX-PGs. The highest levels of drug resistance were associated with either decreased polyglutamation or low levels of TS, an enzyme critical for the depletion of reduced folate pools.

\section{Discussion}

In these experiments we have studied parameters capable of modulating MTX responsiveness in eight patient-derived lines of SCLC. The degree of drug resistance observed in these clinical specimens is relatively low compared to that obtainable in vitro with serial selective passage in increasing drug concentrations. Even in the most resistant of these clinically derived cell lines, clonogenic survival was $<50 \%$ control after a 24 -h exposure to $10 \mu \mathrm{M}$ drug. However, these cell lines did differ over a 100 -fold range in their sensitivity to MTX, and their isolation provides a unique opportunity to examine the factors responsible for clinical drug resistance. Previous examination of the determinants of MTX toxicity in cultured cells and in experimental in vivo models has provided evidence that the ability to kill cells is a function of the presence of free intracellular antifolate.

Under conditions that simulated clinical exposure of tumor cells to MTX ( $1 \mu \mathrm{M}$ drug for $24 \mathrm{~h}$ ), drug saturated the intracellular binding capacity in all cell lines. Drug transport did not, therefore, appear to be a limiting factor responsible for resistance in these cells. The critical determinant of sensitivity to $1.0 \mu \mathrm{M}$ MTX was the ability of cells to form MTX-PGs with 3-5 glutamyl moieties. There was a direct relationship between the formation of the higher polyglutamates and intracellular retention of drug after removal of extracellular MTX. Two cell lines (NCI$\mathrm{H} 209$ and NCI-H128) were highly sensitive to $1.0 \mu \mathrm{M}$ drug exposure (no colony survival), and in both of these lines this exposure produced sufficient MTX polyglutamates to exceed the drug-binding capacity by $>50 \%$ for $24 \mathrm{~h}$ after removal of extracellular drug. In the six remaining lines with relative resistance to $1.0 \mu \mathrm{M}$ drug, formation of these metabolites (MTX-Glu $\mathrm{G}_{3}$ to

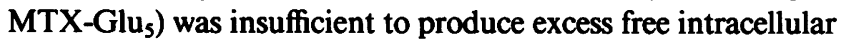
antifolate for $24 \mathrm{~h}$, although the general pattern of retention of higher polyglutamates was similar to that observed in drug-sensitive lines (Fig. 2).

Three of the six cell lines with relative resistance to $1.0 \mu \mathrm{M}$ MTX were unable to survive exposure to $10 \mu \mathrm{M}$ drug (NCI$\mathrm{H} 345$, NCI-H60, and NCI-H187). In these three cell lines, exposure to the higher drug concentrations resulted in sufficient synthesis of MTX-Glu ${ }_{3}$ to MTX-Glu for prolonged maintenance of free intracellular drug (Fig. 3).

Three cell lines demonstrated greater resistance to MTX; NCI-H146, NCI-H524, and NCI-N417D were capable of significant survival ( $>20 \%$ control colony formation) after exposure to $10.0 \mu \mathrm{M}$ drug. In NCI-N417D, MTX polyglutamation remained inefficient during exposure to high drug concentrations. After 24-h incubation in $10 \mu \mathrm{M}$ drug, MTX-Glu 5 was undetectable, and other high molecular weight metabolites were found only in small quantities.

In NCI-H146 and NCI-H524, the specific activity of TS was low (Table I). Since de novo thymidylate synthesis is the only pathway by which reduced folates are oxidized to inactive dihydrofolate, the activity of TS is crucial to antifol sensitivity. Similar results have been reported by Washtien (6), who studied TS levels in five cultured human gastrointestinal tumor cell lines and found a negative correlation between MTX sensitivity and TS specific activity (6).
Table II also shows that there was a consistent increase in MTX binding capacity during the period of drug incubation, that this increase occurred most rapidly at highest drug concentrations, and that the magnitude of this increase was greatest in resistant cell lines. This phenomenon was first reported by Bertino and co-workers $(32,48)$ in tumor cells derived from leukemia patients refractory to MTX treatment. Most recently, Domin and co-workers have shown concentration-dependent induction of DHFR by MTX in drug sensitive and in geneamplified drug-resistant human $\mathrm{KB}$ cell lines in vitro (49). A maximal fivefold increase in enzyme levels was achieved at a concentration of $2.5 \mu \mathrm{M}$ drug. These results are of obvious importance to the expression of resistance, since acute drug-induced increases in DHFR might overwhelm intracellular free drug and make sufficient enzyme available for reduction of oxidized folates. In both the human KB cells and the patient-derived SCLC cell lines, this induction was dose dependent, but limited, in that intracellular drug binding capacity after $24 \mathrm{~h}$ of MTX exposure was generally similar at $1.0-$ and at $10.0-\mu \mathrm{M}$ incubations.

Many factors seemed of lesser importance in predicting drug sensitivity (Table I). There was a poor correlation between doubling time and drug sensitivity. Further, the measured differences in target enzyme affinity for drug were small in comparison to the 250-fold decrease in affinity reported to confer in vitro resistance (23).

We have previously observed elevated DHFR levels associated with gene amplification in an SCLC patient in clinical relapse after treatment with single-agent, high-dose MTX (33). However, this phenomenon was not observed in any of the present cell lines, five of which were derived from patients receiving low doses of MTX as a component of combination chemotherapy.

In summary, we have studied the variables that are known to modulate MTX responsiveness in eight clinically derived cell lines of SCLC. In six of eight lines, the ability of cells to synthesize and retain MTX-PGs in excess of DHFR binding capacity was a primary determinant of sensitivity. MTX metabolism to MTXPGs was dose dependent, and could be increased by raising extracellular drug concentration. Importantly, polyglutamate formation was also time dependent; even the most sensitive SCLC cell lines in this series were unable to metabolize MTX to polyglutamate species after 1-h exposure to drug. Since our data indicate that synthesis and retention of these higher molecular weight species are critical for cytotoxicity, the usual clonogenic assay-which exposes tumor cells to drug for only $1 \mathrm{~h}$-is very limited in determining cellular sensitivity to this drug.

Although prolonged saturation of target enzyme was necessary for toxicity, it was not in itself sufficient. Resistance to MTX could be maintained despite the presence of free intracellular drug in two cell lines that had low specific activity of thymidylate synthase. Thus, MTX resistance in human SCLC is multifactorial, and may or may not be overcome at high drug concentrations.

\section{References}

1. Chabner, B. A. 1982. Methotrexate. In Pharmacologic Principles of Cancer Treatment. B. A. Chabner, editor, W. B. Saunders Co., Philadelphia. 229-255.

2. Goldman, I. D., N. S. Lichtenstein, and V. T. Oliverio. 1968. Carrier-mediated transport of the folic acid analog, methotrexate, in the L1210 leukemia cell. J. Biol. Chem. 243:5007-5017. 
3. Moran, R. G., M. Mulkins, and C. Heidelberger. 1979. Role of thymidylate synthetase activity in development of methotrexate cytotoxicity. Proc. Natl. Acad. Sci. USA. 76:5924-5928.

4. White, S. C., and I. D. Goldman. 1981. Methotrexate resistance in an L1210 cell line resulting from increased dihydrofolate reductase, decreased thymidylate synthetase activity, and normal membrane transport. J. Biol. Chem. 256:5722-5727.

5. Ayusawa, D., H. Kajama, and T. Sevo. 1981. Resistance to methotrexate in thymidylate synthetase-deficient mutants of cultured mouse mammary tumor FM3A cells. Cancer Res. 41:1497-1501.

6. Washtien, W. L. 1982. Thymidylate synthetase levels as a factor in 5-fluorodeoxyuridine and methotrexate cytotoxicity in gastrointestinal tumor cells. Molec. Pharmacol. 21:723-728.

7. White, J. C., S. Loftfield, and I. D. Goldman. 1975. The mechanism of action of methotrexate. III. Requirement of free intracellular methotrexate for maximal suppression of ${ }^{14} \mathrm{C}$-formate incorporation into nucleic acids and protein. Molec. Pharmacol. 21:287-297.

8. Cohen, M., R. A. Bender, R. C. Donehower, C. E. Myers, and B. A. Chabner. 1978. Reversibility of high affinity binding of methotrexate in L1210 murine leukemia cells. Cancer Res. 38:2866-2870.

9. White, J. C. 1979. Reversal of methotrexate binding to dihydrofolate reductase by dihydrofolate. Studies with pure enzyme and computer modeling using network thermodynamics. J. Biol. Chem. 254:1088910895.

10. Jacobs, S. A., R. H. Adamson, B. A. Chabner, C. J. Derr, and D. G. Johns. 1975. Stoichiometric inhibition of mammalian dihydrofolate reductase by the gamma-glutamyl metabolite of methotrexate: 4-amino4-deoxy- $\mathrm{N}^{10}$-methylpteroyl-glutamyl-gamma-glutamate. Biochem. Biophys. Res. Commun. 63:692-698.

11. Clendeninn, N. J., K. H. Cowan, B. T. Kaufman, M. V. Nadkarni, and B. A. Chabner. 1983. Dihydrofolate reductase from a methotrexateresistant human breast cancer cell line: purification, properties and binding of methotrexate and polyglutamates. Proc. Am. Assoc. Cancer Res. 24:276.

12. Fry, D. W., J. C. Yalowich, and I. D. Goldman. 1982. Rapid formation of poly-gamma-glutamyl derivatives of methotrexate and their association with dihydrofolate reductase as assessed by high-pressure liquid chromatography in the Ehrlich ascites tumor cells in vitro. J. Biol. Chem. 257:1890-1896.

13. Jolivet, J., R. L. Schilsky, B. D. Bailey, and B. A. Chabner. 1982. Synthesis, retention, and biological activity of methotrexate polyglutamates in cultured human breast cancer cells. J. Clin. Invest. 70:351360.

14. Jolivet, J., and B. A. Chabner. 1983. Intracellular pharmacokinetics of methotrexate polyglutamates in human breast cancer cells: selective retention and less dissociable binding of $4-\mathrm{NH}_{2}-10-\mathrm{CH}_{5}-\mathrm{PteGlu}_{4}$ and ${ }_{5}$ to dihydrofolate reductase. J. Clin. Invest. 72:773-778.

15. Rosenblatt, D. S., V. M. Whitehead, N. Vera, A. Pottier, M. Dupont, and M. J. Vuchich. 1978. Prolonged inhibition of DNA synthesis associated with the accumulation of methotrexate polyglutamates by cultured human cells. Molec. Pharmacol. 14:1143-1147.

16. Balinska, M., J. Galivan, and J. K. Coward. 1981. Efflux of methotrexate and its polyglutamate derivatives from hepatic cells in vitro. Cancer Res. 41:2751-2756.

17. Curt, G. A., J. Jolivet, B. D. Bailey, D. N. Carney, and B. A. Chabner. 1984. Synthesis and retention of methotrexate polyglutamates by human small cell lung cancer. Biochem. Pharmacol. 33:1682-1685.

18. Baggott, J. E. 1983. Inhibition of purified avian liver aminoimidazole carboxamide ribotide transformylase by polyglutamates of methotrexate and oxidized folates. Fed. Proc. 42:662.

19. Szeto, D. W., Y.-C. Cheng, A. Rosowsky, C.-Y. Yu, E. J. Modest, J. R. Piper, C. Temple, Jr., R. D. Elliott, J. D. Rose, and J. A. Montgomery. 1977. Human thymidylate synthetase. III. Effect of methotrexate and methotrexate analogs. Biochem. Pharmacol. 28:2633-2637.

20. Hill, B. T., B. D. Bailey, J. C. White, and I. D. Goldman. 1979. Characteristics of transport of 4-amino antifolates and folate compounds by two lines of L5178Y lymphoblasts, one with impaired transport of methotrexate. Cancer Res. 39:2440-2446.

21. Sirotnak, F. M., D. M. Moccio, L. E. Kellehey, and L. J. Contas. 1981. Relative frequency and kinetic properties of transport-defective phenotypes among L1210 cloned cell lines derived in vivo. Cancer Res. 41:4447-4452.

22. Ohnoshi, T., T. Ohnuma, I. Takehashi, K. Scanlon, B. A. Kamen, and J. F. Holland. 1982. Establishment of methotrexate-resistant human acute lymphoblastic leukemia cells in culture and effects of folate antagonists. Cancer Res. 42:1655-1660.

23. Flintoff, W. F., and K. Essani. 1980. Chinese hamster ovary cells contain a dihydrofolate reductase with altered affinity for methotrexate. Biochemistry. 19:4321-4327.

24. Haber, D. A., S. M. Beverley, M. L. Kiely, and R. T. Schimke. 1981. Properties of an altered dihydrofolate reductase encoded by amplified genes in cultured mouse fibroblasts. J. Biol. Chem. 256:95019510.

25. Jackson, R. C., and P. Neithammer. 1977. Acquired methotrexate resistance in lymphoblasts resulting from altered kinetic properties of dihydrofolate reductase. Eur. J. Cancer. 13:567-575.

26. Alt, F. W., R. E. Kellems, and R. T. Schimke. 1976. Synthesis and degradation of the folate reductase in sensitive and methotrexateresistant lines of S-180 cells. J. Biol. Chem. 251:3075-3080.

27. Melera, P. W., J. A. Lewis, J. L. Biedler, and C. Hessean. 1980 Antifolate-resistant Chinese hamster cells: evidence for dihydrofolate reductase gene amplification among independently derived sublines overproducing different dihydrofolate reductase. J. Biol. Chem. 255:70247028.

28. Alt, F. W., R. E. Kellems, J. R. Bertino, and R. T. Schimke. 1978. Selective multiplication of dihydrofolate reductase genes in methotrexate-resistant variants of cultured murine cells. J. Biol. Chem. 253 $1357-1370$

29. Cowan, K. H., M. E. Goldsmith, R. M. Levine, S. C. Mitken, E. Douglas, N. Clendeninn, A. W. Nienhuis, and M. E. Lippman. 1982. Dihydrofolate reductase gene amplification and possible rearrangement in estrogen-responsive methotrexate-resistant human breast cancer cells. J. Biol. Chem. 257:15079-15086.

30. Kaufman, R. J., P. C. Brown, and R. T. Schimke. 1979. Amplified dihydrofolate reductase genes in unstably methotrexate-resistant cells are associated with double minute chromosomes. Proc. Natl. Acad. Sci. USA. 76:5669-5673.

31. Cowan, H. K., and J. Jolivet. 1984. A methotrexate-resistant human breast cancer cell line with multiple defects, including diminished formation of methotrexate polyglutamates. J. Biol. Chem. 259:1079310800 .

32. Bertino, J. R., A. Cashmore, M. Fink, P. Calabresi, and E. Lefkowitz. 1965. The "induction" of leukocyte and erythrocyte dihydrofolate reductase by methotrexate. Clin. Pharmacol. Ther. 6:763-770.

33. Curt, G. A., D. N. Carney, K. H. Cowan, J. Jolivet, B. D. Bailey, J. C. Drake, C. S. Kao-Shan, J. D. Minna, and B. A. Chabner. 1983. Unstable methotrexate resistance in human small cell carcinoma associated with double minute chromosomes. N. Engl. J. Med. 308:199202.

34. Horns, R. C., W. J. Dower, and R. T. Schimke. 1984. Gene amplification in a leukemia patient treated with methotrexate. J. Clin. Oncol. 2:2-7.

35. Trent, J. M., R. N. Buick, S. Olsen, R. C. Horns, and R. T. Schimke. 1984. Cytologic evidence for gene amplification in methotrexate-resistant cells obtained from a patient with ovarian adenocarcinoma. J. Clin. Oncol. 2:8-15.

36. Carman, M. D., J. H. Schornagel, R. S. Rivest, S. Srimatkandada, C. S. Portlock, T. Duffy, and J. R. Bertino. 1984. Resistance to methotrexate due to gene amplification in a patient with acute leukemia. $J$. Clin. Oncol. 2:16-20.

37. Curt, G. A., K. H. Cowan, and B. A. Chabner. 1984. Gene amplification in drug resistance: of mice and men. J. Clin. Oncol. 2:62-64. 
38. Cohen, M. H., D. C. Ihde, P. A. Bunn, Jr., B. E. Fossieck, Jr., M. J. Matthews, S. E. Shackney, A. J. Early, R. Makuch, and J. D. Minna. 1979. Cyclic alternating combination chemotherapy for small cell bronchogenic carcinoma. Cancer Treat. Rep. 63:163-170.

39. Gazdar, A. F., D. N. Carney, E. K. Russell, H. L. Sims, S. B. Baylin, P. A. Bunn, Jr., J. G. Gurrion, and J. D. Minna. 1980. Establishment of continuous, clonable cultures of small-cell carcinoma of the lung which have amine precursor uptake and dicarboxylation cell properties. Cancer Res. 40:3502-3507.

40. Carney, D. N., P. A. Bunn, A. F. Gazdar, J. A. Pagan, and J. D. Minna. 1981. Selective growth in serum-free hormone-supplemented medium of tumor cells obtained by biopsy from patients with small cell carcinoma of the lung. Proc. Natl. Acad. Sci. USA. 78:3105-3109.

41. Salmon, S. E., A. W. Hamburger, B. Soehnlen, B. G. M. Durie, D. S. Alberts, and T. E. Moon. 1978. Quantitation of differential sensitivity of human-tumor stem cells to anticancer drugs. $N$. Engl. J. Med. 298:1321-1327.

42. Hamburger, A. W., and S. E. Salmon. 1977. Primary bioassay of human tumor stem cells. Science (Wash. DC). 197:461-463.
43. Osborn, M. J., and F. M. Huennekens. 1958. Enzymatic reduction of dihydrofolate reductase. J. Biol. Chem. 233:969-974.

44. Lowry, O. H., N. S. Rosenbrough, A. I. Farr, and R. I. Randall. 1951. Protein measurement with the folin phenol reagent. J. Biol. Chem. 193:265-275.

45. Myers, C. E., M. E. Lippman, H. M. Eliot, and B. A. Chabner. 1975. Competitive protein binding assay for methotrexate. Proc. Natl. Acad. Sci. USA. 72:3683-3686.

46. Scatchard, G. 1949. The attraction of protein for small molecules and ions. Ann. NY Acad. Sci. 51:660-697.

47. Roberts, D. 1966. An isotopic assay for thymidylate synthetase. Biochemistry. 5:3546-3548.

48. Hillcoat, B. L., V. Swett, and J. R. Bertino. 1967. Increase of dihydrofolate reductase activity in cultured mammalian cells after exposure to methotrexate. Proc. Natl. Acad. Sci. USA. 58:1632-1637.

49. Domin, B. A., S. P. Grill, K. F. Bastow, and Y.-C. Cheng. 1982. Effect of methotrexate on dihydrofolate reductase activity in methotrexate-resistant human KB cells. Molec. Pharmacol. 21:478-482. 